\title{
Comparative Analyses of Adult Education Systems of England, Denmark, and Turkey in the Context of The Lifelong Learning Policies of the European Union ${ }^{1}$
}

\begin{tabular}{lccc}
\hline ARTICLE TYPE & Received Date & Accepted Date & Published Date \\
Review Article & 02.10 .2020 & 02.01 .2021 & 02.02 .2021 \\
\hline Rabia Vezne & iD 2 & \\
Akdeniz University & \\
Ahmet Yıldız iD 3 & \\
Ankara University &
\end{tabular}

\begin{abstract}
The purpose of this study is to make a comparative analyse of goals, structure, and legal liability in adult education systems in England, Denmark, and Turkey. Since these countries are member, ex-member, or candidate countries of the European Union, the Union's lifelong learning policies were also taken into consideration while doing the comparison. The method of the research is comparative adult education. This study does not include human subjects, thus ethics committee approval decision is not needed. The goals, structure, and legal liability of England, Denmark, and Turkey's adult education systems were compared. The findings showed that these three countries' adult education targets are parallel with the EU's lifelong learning goals. According to the analyses of the adult education structure, it has been noted that the local governments are active in England. In Denmark, three different stakeholders can be seen and they reach a wider group. On the other hand, Turkey's adult education is a public service. Whereas local authorities are responsible for legal liability in England, state and associations are responsible for it in Denmark. The central government is responsible for legal liability in Turkey. It was showed that the adult education provision in Denmark is much more withstanding than the one in Turkey and England.
\end{abstract}

Keywords: Comparative adult education, adult education systems.

\footnotetext{
${ }^{1}$ This artcile is a part of doctoral dissertation called 'Comparative Analyses of Adult Education Systems of England, Denmark and Turkey in the Context of the Lifelong Learning Policies of the European Union'. Advisor of the dissertation is Assoc. Prof. Dr. Ahmet Yildiz.

${ }^{2}$ Corresponding Author: Asst. Prof. Dr., Faculty of Education, Departmant of Educational Sciences, e-mail: rabiavezne@akdeniz.edu.tr, https://orcid.org/0000-0002-0137-3613

${ }^{3}$ Assoc. Prof. Dr., Faculty of Education, Departmant of Educational Sciences, e-mail: ahmety72@yahoo.com, https://orcid.org/-0000-0002-0158-6168
} 
Recently, using adult education (AE) concept discourse has become widespread as part of lifelong learning (LLL). In recent years, national and international organizations working in this field have preferred LLL concept instead of AE (Milana, 2012). It is seen that LLL concept is being frequently used and discussed in different platforms such as; governments, academics, and media (Nicholls, 2000). Especially, United Nations Educational, Scientific and Cultural Organization's (UNESCO) Faure Report called "Learning To Be" helped the concept to get out and spread. According to this report, educational provisions went out of school and educational fields related to daily life needs have been developed with the help of LLL. As it is understood from this emphasis, learning process in LLL concept has been expanded to all educational fields for individuals' different educational needs during their lifetime. In this context, it involves formal learning, nonformal and informal learning. Moreover, LLL means acquiring and updating knowledge, value, skills, and competencies throughout an individual's life (Demirel and Yağc1, 2012).

The increase in the emphasis on LLL in educational policies is parallel with the spread of globalization discourses (Rizvi and Lingard, 2000). Hence, the emphasis of LLL has increased even more with globalization discourses. It is stated that it is being boosted because of the need for global power and creating knowledge society in most of the European Union (EU) countries (Prokou, 2004). Thus, 1996 was an important year for the European Commission (EC). It was the European Year of LLL and therefore, the concept started to be used widely in Europe.

Lately, it is seen that the EU's LLL policies have structured AE systems of the EU member and candidate countries. Green (2005) examined different LLL models of countries in his study and he stated that the main differences in these models can be grouped in three models:

- Voluntary partnership: Holland and England.

- Formalised social partnership: Austria, Germany, Belgium, Denmark, Finland, Norway and Sweden.

- State-led social partnership: France, Luxemburg, Portugal, Spain, Italy, Greece, and Turkey.

In this study, Green's classification was taken as the basis, and it is aimed to compare England, Denmark, and Turkey's AE systems. During the comparative analyses, goals, structure, and legal liability aspects were taken into consideration within the context of the LLL policies of the EU. Several questions were asked to reach the general aim of the study. The researchers tried to investigate what kind of LLL perspective is suggested to member/candidate countries by EU; how EU's LLL policies reflect on the aim and goals of $\mathrm{AE}$ in these countries; what are the common features and distinctness in the structure of these education systems are; what the common features and distinctness in the legal liability in these education systems are. 


\section{Method}

In this study, the comparative adult education method is used. In this method, England, Denmark, and Turkey's AE systems were examined. The elements of AE systems are examined separately and similarities and differences were tried to be determined. The following elements of the AE systems of the countries were compared in the year of this study: Aims and goals, the structure of the AE systems, and legal liability.

The compared countries were chosen according to the classification in Green's (2005) study in which the author states that the important differences occur especially between voluntary partnership, formalised social partnership, and state-led social partnership. Therefore, the compared countries were chosen according to these three models. In the study, England was chosen for voluntary partnership, Denmark was chosen for formalised social partnership, and Turkey was chosen for state-led social partnership. The AE systems of these three countries were compared.

The data were collected with document analyses. A literature review was done for document analyses, then the categories were determined to make the comparison in the context of AE systems. These categories were chosen from Eurydice which collects and gives information about the education systems of the European countries. Taking these categories from Eurydice made reaching the data easy. The structure and legal liability of AE were basically taken from Eurydice categories. Besides Eurydice data, the publications and websites of universities and ministries of education and educational networks were used to collect data.

The EU has published numerous policy papers related to LLL since 1993 and its LLL objectives were set in 1993. Moreover, the EU's latest policy document including LLL was Education and Training 2020 (ET 2020) (EC, 2009). In 2011, the EU published the implementation of the Strategic Framework for the European cooperation in education and training (ET, 2020) — 'Education and Training in a smart, sustainable and inclusive Europe'. Therefore, 15 policy papers published first in 1993 and 2011 were used in this study. This is a document analysis study. The data got within the scope of research questions were analysed with descriptive analysis. In the descriptive analysis process, a literature review was done in accordance with the research aim, the sub-categories related to LLL policies were determined, and the data were collected within the frame of these sub-categories. The similarities and differences were presented in accordance with comparative education method. Based on research questions, a frame was developed for data analysis, and the data were chosen according to this frame, organised, similarities and differences were brought together, tables were formed and interpreted.

The goals of AE, structure and legal liability in AE systems of these countries were compared according to the data taken from Eurydice, and the similarities and differences were presented. Moreover, while interpreting these similarities and differences, the interpretations were addressed to the countries' economic, social, and political structures. Therefore, the data were not just written one by one, but also the 
reasons for similarities and differences were tried to be explained in accordance with the nature and aim of the comparative education. Moreover, this study does not include human subjects, thus ethics committee approval decision is not needed.

\section{Results}

In this part, the researchers tried to present what kind of LLL perspective is suggested to member/candidate countries by the EU; how the EU's LLL policies reflect on the aim and goals of $\mathrm{AE}$ in these countries; what are the common features and distinctness in the structure of these education systems are; what the common features and distinctness in the legal liability in these education systems are.

\section{EU's Lifelong Learning Policy}

When the basic papers published by the EU are examined, it is seen that the EU wanted to use LLL to become competitive and dynamic knowledge based economy. The relationship between personal development and social development is underlined and it is emphasised that competitiveness is inevitable. Hence, Field (2010) stated that the EC mentioned LLL and especially competitiveness, employment, and development. Similarly, Smith (2002) noted that LLL policies are trying to integrate employment and education, and it became the basic subject of the European Council Meeting in 2000 in Lisbon for the EU's strategy of continuous economic growth and social cohesion.

Growth, Competitiveness, Employment (EC, 1993) paper is an indicator that shows education is degraded to a process that produces human capital and education is formalized in the direction of employment markets. The following emphasis in White Paper draws attention:

All measures must therefore necessarily be based on the concept of developing, generalizing and systematising lifelong learning and continuing training. This means that education and training systems must be rethought in order to take account of the need ... The establishment of more flexible and more open systems of training and the development of individuals' ability to adapt will become increasingly important, both for businesses, so that they can make better use of the technological innovations they develop or acquire, and for individuals, a considerable proportion of whom may well have to change their line of work four or five times during their lives (EC, 1993, s.120).

As it can be understood from the emphasis in White Paper, human capital which increases competitiveness, renewing oneself continuously, produces knowledge, and learning to learn has become the main indicator of education policies. As to education, it is degraded to developing the competencies of human capital in labour market.

In ET 2020 strategic framework, the first objective is making LLL and mobility a reality. It is especially emphasised that LLL is very essential for employment in this objective: 
Strategic objective 1: The challenges posed by demographic change and the regular need to update and develop skills in line with changing economic and social circumstances call for a lifelong approach to learning and for education and training systems that are more responsive to change and more open to the wider world. ... In particular, work is needed to ensure the development of national qualifications frameworks based on relevant learning outcomes and their link to the European Qualifications Framework ... Further efforts are also required to promote adult learning, to increase the quality of guidance systems, and to make learning more attractive in general - including through the development of new forms of learning and the use of new teaching and learning technologies (EC, 2009. p.3).

As it is seen, ET 2020 strategic objective one generally repeats the EU's objectives set in 1993. The emphasis is on enhancing skills, practicing coherent and comprehensive LLL strategies in the EU member countries, developing national qualifications frameworks which is coherent with the European Qualifications Framework, recognizing learning outcomes, increasing the quality of guidance systems, and encouraging mobility for all.

Accordingly, education is standardised with qualification frameworks. In addition to standardization, education has started to be measured via international standard tests. Thus, competition in education has been moved to an international level. This standardization and measurement with international tests have become a current issue in countries. Moreover, education of adults who are out of formal education or in labour market has become essential. Adults' gaining new skills also draws attention. The main reason for the point on LLL is to make these targets real. Generally, it can be said that four priorities are emphasised in all the documents published by the EU between 1993 and 2011. These priorities are labour market and employment, social inclusion and active citizenship.

As a result, emphasised words in most of the EU publications are economic growth, competitiveness, and employment. Personal and social development are linked directly with economic development, and it is stated that competitiveness is inevitable. Eventually, competition in education has moved to an international level with qualification frameworks and international tests. In particular, the importance of gaining new skills for adults has been underlined. To reach these targets, LLL is underlined.

It is observed that the public nature of AE has depreciated significantly with the start of its being mentioned with LLL concept. Programmatic integrity of AE is broken up as a consequence of the reduction in public funds and commercialization. Neoliberal policies and human capital approach bring vocational training into the forefront (Say1lan, 2001). Hence, Prokou (2004) also stated that global trends support LLL in most of the EU countries and correspondingly there is an increase in employment-oriented educational programs while there is a decrease in the general AE programs. In other words, recently while the vocational training aspect of AE has 
been organised according to the demands of the market and has been linked to international standards, socialist aims and social aspects of $\mathrm{AE}$ have been assigned to civil society (Sayılan, 2001).

\section{Comparing the Goals of AE in England, Denmark, and Turkey}

LLL policies, accordingly goals of AE, in England focus on gaining skills to work force and follow a policy which serves labour market. Kogan (2000) stated that there is no legal and regulatory framework related to LLL in the United Kingdom, and government policies in this field are encouraging, but loud and clear policies have not been determined. Conditions related to LLL and AE have been set with Skills Strategy in England. In this strategy, it is underlined that individuals and employers should contribute to the educational costs since especially public funds are limited. The goals of $\mathrm{AE}$ in England have taken shape with a market approach by neoliberal policies. The clear indicator of this is that LLL and AE are in "Skills for Sustainable Growth: Strategy Document" (Department for Business, Innovation and Skills [BIS], 2010). With "Rigour and Responsiveness in Skills (BIS, 2013)" strategy which is updated in 2013, the goals of AE in England have been focused on theworking force's gaining qualifications, and with this strategy, a policy which serves the market has been followed. The goal and target are building a flexible system that prepares all the conditions to train workers with the demands of employers. Kogan (2000) states that LLL is associated with competitiveness, being market-oriented, and the needs of industry and business world in various policy documents.

In Denmark, there is an AE system that aims to increase participation in democratic life, personal development, and life quality; ensuring equality with education, and improving vocational competencies. In Denmark's LLL strategy document, the goal of LLL starts with equal opportunity for all (Danish Ministry of Education [DMoE], 2007). However, after that, it is stated that education should be compatible with labour market. Besides, guidance and counseling services takes place in goals. These services include a guidance and counseling which helps adults to choose a proper education program for themselves and attend LLL. Moreover, a strategy that aims the recognition of prior learning and a transparent education system is adopted. It is seen that Denmark's LLL strategy has been affected by globalization and it reflects EU's LLL policy with its goal which states that a global approach in educational programs will enhance cooperation in international platforms (DMoE, 2007). Hence, Larson and Milana (2011) also expressed that AE policies are shaped by global competition and Lisbon Strategy, AE is used as a tool of labour market and economy policies, and $\mathrm{AE}$ is considered as a way of increasing competitiveness.

In the Turkish Republic, which has a central administration and a high young population rate, the Turkish Ministry of Education (TMoE) manages all the educational activities from the center. Turkey, 69th in the human development index, has been a candidate member of the EU since 1999 (United Nations Development Programme [UNDP], 2015). 
In Basic Law of National Education No. 1739, the specific goals of non-formal education which includes $\mathrm{AE}$ can be summarised as teaching reading and writing, providing continuous education, providing educational opportunities which help to complies with the scientific and technological developments of the era, and provide employment which comply with employment policy for economic development.

Turkey, while continuing the EU harmonization studies, prepared 2009-2013 and 2014-2018 Lifelong Learning Strategy Documents and shaped the goals of AE and LLL. The first document prepared for the 2009-2013 period is one-to-one adaptation of EU's LLL strategy documents with regard to content and format. As to 2014-2018 Lifelong Learning Strategy Document, it focuses especially on generation of LLL culture and awareness in the society, increasing access to LLL, increasing opportunities and provision, developing a lifelong guidance and counseling system, developing the system of evaluation of previous learning, and developing a LLL monitoring and evaluation system. In both Denmark and Turkey's strategy documents, there is a focus on recognition of previous learning and guidance and counseling services.

According to Bağc1 (2011), in the EU membership process Turkish education system has been tried to be harmonised with the EU countries' systems. In this membership process, Turkey's education system was tried to be compatible with the EU's system, and LLL documents have been prepared based on the EU documents related to LLL. For this reason, there are many similarities between the EU's and Turkey's documents in terms of the language used, educational needs, and goals. Bağc1 (2011), noted that although Turkey has distinctive problems related to LLL and need special solutions for these problems, dynamics of the EU membership and globalization are based in Turkey's LLL policies, and Turkey's distinctive problems are ignored. Thus, Yildiz (2012) also pointed out that basic documents that leads Turkey's education are formed with a neoliberal approach and according to the demands of the market.

In a general review, the first and the most important remarkable thing is that these three countries are affected directly by the EU's LLL policies. However, all countries are not affected at the same level and in a similar way. Countries' own AE history and LLL models make this level different. In England, LLL policies and accordingly AE goals focus on gaining quality to employees and follow a policy that serves to market. In Denmark and Turkey, although the LLL strategy documents are prepared according to EU's LLL strategy, the right to AE is prioritised. For Denmark, this situation can be explained by having an organized and democratic society coming from the past. Regarding Turkey, the goals of LLL focus on providing continuous education opportunities, providing educational opportunities that are compatible with the scientific and technological needs of the era, and providing employment that are compatible with the employment policies for economic development. The reason for the emphasis on especially generation of LLL culture and consciousness in the society, increasing opportunities and provision, increasing access to LLL, developing 
a lifelong guidance and counseling system, developing the system of evaluation of previous learning, and developing a LLL monitoring and evaluation system in 20142018 Lifelong Learning Strategy Document is results from the higher shortcomings in these fields.

\section{Comparing the Structure of AE in England, Denmark, and Turkey}

In England, Denmark, and Turkey which are representing three different models, the structure of AE systems are different from each other. As can also be seen in Table 1, in England, representing voluntary partnership, there is a structure in which private and voluntary organizations focusing on vocational education are active. In Denmark, representing formalised social partnership, there is a structure which is conducted by public and non-governmental organizations (NGOs). In Turkey, representing state-led social partnership, there is a structure mostly conducted by the public and focused on vocational education. Especially in Turkey, it is remarkable that there are different organizations. While in Denmark, the AE structure is separated into three groups, in Turkey it is separated into eight different groups which are mostly public bodies. All these institutions are organised and inspected by the TMoE.

Table 1

The Structure of AE in Three Countries

\begin{tabular}{ll}
\hline Countries & The Structure of AE \\
\hline England & Further Education Colleges (FE) \\
& Community Learning Providers \\
& Private or Voluntary (Third) Sector Training Organizations \\
& Open and Distance Education \\
& Institute of Technology \\
\hline Denmark & Non-Formal AE (NGOs) \\
& General AE (AVU) (State) \\
& Vocational AE (State) \\
\hline Turkey & TMoE /Directorate General for Lifelong Learning (DGLL) \\
& TMoE / Directorate General for Vocational and Technical \\
& Education (DGVTE) \\
& Public Education Centers/DGLL \\
& Maturation Institutions/DGLL \\
& Open Schools \\
& Distance Education Institutions \\
& Private Education Institutions \\
\hline
\end{tabular}

In 2016 BIS was responsible for AE in England. Giving the responsibility to a department whose name includes business and skills shows that the main goal of the $\mathrm{AE}$ is perceived as providing job and skills-building to individuals. There are many different organizations providing AE under the coordination of this Department. The most common of these organizations are Further Education Colleges which organise 
especially vocational and technical courses. As can also be seen in Table 1, the other institution which provides AE is community learning providers. These institutions include local authorities and voluntary organizations and provide these services in $\mathrm{AE}$ centers, community centers, libraries, schools, children centers, and other places. Institutions which are providing AE with the public fund are Private or Voluntary (Third) Sector Training Organizations. Just like further education colleges, they see job provision as the main goal and provide work-based learning provisions. Apart from these, there are National Extension College (NEC) which provides open and distance education, Futurelearn: Massive Open Online Course platform, Learndirect, and Open University.

Statistical Office of the European Union-EUROSTAT 2016 published Lifelong Learning Statistics in 2016. According to these statistics, participation in AE in England $(20.1 \%)$ is considerably higher than in Europe $(16.6 \%)$. With this high participation rate, there is a structure of an AE containing organizations focused on business, skills, and providing jobs in England. The main role of AE was providing individuals' basic educational needs and contributing their personal development, but it is seen that this role is replaced by providing job. AE reaches the aim of providing job for individuals by using the current organizational structure. High participation rates also show that individuals' preferences are determined by the market condition.

When the structure of AE in Denmark is examined, three different structures that provide AE can be seen at first (DMoE, 2016c). As it is also shown in Table 1, these are non-formal AE, general AE and vocational AE. According to EUROSTAT 2016 Lifelong Learning Statistics, the participation rate to AE in Denmark is 37.4\%. This can be interpreted as a clear indicator of the fact that AE provisions are successful in Denmark. First of all, continuing comprehensive non-formal AE by different organizations and providing predominantly general AE besides vocational education show that the tradition of a famous educator called Nikolai Frederik Severin Grundtvig has been retained. Detailed information related to Denmark's non-formal AE activities is given in Eurydice (EAEAC Eurydice, 2016b). Non-formal AE activities are carried by NGOs without any exams. In this context, university extension courses, day folk high schools, evening schools, and folk high schools provide AE. DMoE (2016a) states that non-formal AE is provided to general and academic insight and skills with the help of about 1800 evening schools and voluntary activity in associations. The indicator of the success of Denmark's AE provisions is that each year about 700,000.00 people attend these independent non-formal AE activities. Besides, the university extramural department provides distance learning. Day folk high schools provide non-formal AE for those who are out of formal education, personally or socially vulnerable to provide job for them. Private independent boarding schools are also the $\mathrm{AE}$ organizations that provide courses about home economics, arts and crafts. The courses' main targets are the interpretation and meaning of life, $\mathrm{AE}$ and democratic education. Denmark's non-formal AE provision reveals that $\mathrm{AE}$ is being carried successfully with four different organization types throughout the country (DMoE, 2016a). 
Apart from non-formal AE, there is also a general AE provision in Denmark. The aim is to improve or supplement adults' knowledge and skills in general subjects. There are three levels of AE including preparatory $\mathrm{AE}$, general $\mathrm{AE}$, and single subject courses. This structure is parallel to Denmark's formal education system, and individuals can reach education at all levels and enter exams throughout their lifetime (EAEAC Eurydice, 2016a).

There is also an adult vocational training provision for employees who have low skills in Denmark. However, this provision is not as common as non-formal AE provision. Moreover, social stakeholders take an important part in the management, assigning priorities, development, and organization (EAEAC Eurydice, 2016a). Financing this provision by the public is another important difference in Denmark's AE system.

$\mathrm{AE}$ is carried out by DGLL under the TMoE in Turkey as it is seen in Table 1. Unlike Denmark, AE is formed with a centralised structure. DGVTE under the TMoE is also a part of this structure. Curriculums, course durations, many elements related to trainers are determined by the TMoE. Public education centers, maturation institutions, open schools, and distance education institutions also take place in this structure. Besides these, private education institutions and private courses also provide non-formal AE services. According to EUROSTAT 2016 Lifelong Learning Statistics, the participation rate to AE in Turkey is $11.2 \%$. This rate is below the EU's rate $(16.6 \%)$. This rate was reached with especially young people who attend vocational courses. The participation rate in courses which improve adults' general skill and socio-cultural courses are lower. Moreover, although there is less focus on vocational training in the strategy document, focusing on vocational training in the $\mathrm{AE}$ structure is quite a few, and most of the courses are aimed at providing in $\mathrm{AE}$ jobs.

\section{Comparing the Legal Liability in AE in England, Denmark, and Turkey}

In England, Denmark, and Turkey which are representing three different models, the legal liability in AE systems are different from each other. As can also be seen in Table 2, in England, representing voluntary partnership, the legal liability is on local authorities. In Denmark, representing formalised social partnership, the legal liability is on social partners. In Turkey, representing state-led social partnership, the legal liability is on the state. The LLL models of these countries are parallel to the distribution of legal liability in these countries. 
Table 2

Legal Liability in AE in Three Countries

\begin{tabular}{ll}
\hline Countries & \multicolumn{1}{c}{ Legal Liability in AE } \\
\hline England & -Responsibility was given to local authorities with 2009 Act \\
& -Department of Education (DfE) (Regulation Responsibility) \\
& -Skills Funding Agency (SFA) (Financial Responsibility) \\
& -The Office of Qualifications and Examinations Regulation \\
& (Ofqual) (Inspection Responsibility) \\
\hline Denmark & -The Act on General AE 2008 \\
& -The Act on Adult Vocational Training Courses \\
& -The Act on Non-Formal AE Activity \\
\hline Turkey & -TMoE. \\
& -Statutes (1739, 6764, 3308, 5544) \\
& -Regulations (2008, 2010)
\end{tabular}

In England, legal liability related to planning, implementation, and financing of AE was given to local authorities with the 2009 Act. However, the legal liability was on local authorities before 1993. Between 1993 and 2009, incorporated further education colleges became independent from local authorities and in 2009 all responsibilities were given to local authorities again. While $\mathrm{AE}$ has been in the jurisdiction of BIS since 2016, Theresa May, the prime minister, gave the duty to the Department of Education. As it is understood, the role of AE was seen as providing jobs and improving skills since 2016. The organizations which are responsible for AE were generally organizations focused on skills and employment: Sector Skills Councils, National Skills Academies, Local Enterprise Partnerships, Education and Training Foundation, Association of Colleges, and Association of Employment and Learning Providers. As it is shown in Table 2, the Skills Funding Agency (SFA) is responsible for the financial issues of AE organizations under BIS. Ofqual is the one that is responsible for the inspection of $\mathrm{AE}$ organizations.

In Denmark, general AE is regulated with The Act on General AE 2008 Statute No 311 by DMoE. Besides, The Act on Adult Vocational Training Courses and The Act on Non-Formal AE Activity are the acts used for legal liability in AE. Moreover, in accordance with formalised social partnership model, many non-governmental organizations share the responsibility. In Denmark, Denmark Adult Education Association, Adult Education Centers (VUC) Leaders Union, and social partners (workers union and employers foundation) takes the responsibility in vocational $\mathrm{AE}$ (DMoE, 2016b).

Having a centralised model, there are four different statutes which are regulating AE in Turkey. These statutes are Basic Law of National Education No. 1739, Decree Law on Organization and Duties of Ministry of National Education No. 6764, Vocational Education Law No. 3308 and Vocational Qualifications Institution Law No. 5544. Apart from these statutes, there are two by-laws. These by-laws are 
Regulation on Non-Formal Education Institutions (2010) and Regulation on Vocational and Technical Education (2008).

When we compare these three countries in the context of legal liability, in England although there are superior institutions that are responsible for organization, financing, and inspection, responsibility and executive function are on local authorities. Whereas in Denmark, although the responsibility is shared with social partners, the regulation is carried out with laws and acts. When it comes to Turkey, $\mathrm{AE}$ is regulated with laws, by-laws, and directives in a detailed way and under the control of the centralized administration. It is seen that the distribution of the legal liability in the countries is compatible with their LLL models stated by Green's (2005) classification. In England which represents the voluntary partnership model, the responsibility is on local authorities. In Denmark, although the state shares the responsibility with social partners, it keeps the regulation and inspection on itself with laws and statutes. In Turkey which represents state model, the legal liability is on state with laws, by-laws, and directives.

\section{Discussion, Conclusion and Suggestions}

Since the 1990s, the EU's LLL policies are shaped by the effects of globalization. Especially, the human capital approach has become the main determiner of the education policies. According to this human capital approach, the most important element is the individuals who will increase competition, renew themselves continuously, produce knowledge, and know learning to learn. There is an increasing focus on the fact that individuals have to change their job four or five times in their lifetime, and they have to improve their skills because of this. Having a lack of knowledge and skills is seen as the reason for unemployment for individuals. For that reason, it is emphasized in various publications that LLL has to be more flexible and serve the market.

In the Lisbon Summit, LLL is emphasised as being the center of the development in labour market policies. In particular, it is stated that new key competencies that will be gained through LLL need to be identified. It is underlined that one of the essential fields for the EU's being the most agonistic and knowledge-based economy is LLL, and LLL has been loaded with a charge of educating human resources needed for a new era. In the European Area of Lifelong Learning, the duty of LLL is stated as creating a European area where there is a more flexible and rich labour force.

In all most all the documents published by the EU, there is a strong emphasis on economic growth, competitiveness, and employment. Competitiveness is presented as an inevitable element by linking personal and social development with economic development. Accordingly, education has been standardized with qualification frameworks and assessed with international tests. As a result of this standardization and international tests, competition in education has moved to an international level. In particular, great importance was given to the education of adults who are out of formal education or who entered working life. The importance of gaining new skills 
to those adults has been underlined. To reach all these goals, the emphasis on LLL has increased.

The four priorities emphasized in the EU's policy documents since the 1990s are labour market, employment, social inclusion, and active citizenship. The EU gives LLL the duty of improving individuals' competitiveness and employability skills to develop the knowledge-based economy. Besides this, the EU gives LLL the duty of including all citizens and teaching active citizenship to realise its goal of only Europe Citizenship.

Although the EU does not specify a common education policy among member countries, it is seen that the AE policies of the compared countries are compatible with EU's common principles and values in the field of education. However, each country has not affected by the EU's LLL policies at the same level. Countries' own AE history and LLL models make this effect level different.

The EU's AE strategy plays an important role in the competition, employment, social inclusion, and active citizenship policies, and the goals of $\mathrm{AE}$ are shaped accordingly. There is an emphasis on improving adults' skills and competencies throughout their lifetime in the EU's ET 2020 strategy (EC, 2009). Especially, the attention is drawn to the services for adults who are lack of key competencies and did not complete primary education.

It is seen that the AE goals of the compared countries are parallel with the LLL goals of EU. In England, LLL policies and AE goals are focused on qualified employees and follow a policy that serves the market. In Denmark, among the goals of LLL are equal opportunity for all and education which is compatible with labour market. Besides, guidance and counseling services, the recognition of prior learning and a transparent education system are aimed at the strategy. It is seen that Denmark's LLL strategy is highly affected by globalization and the EU's LLL policies with its goal which states that a global approach in educational programs will enhance cooperation in international platforms. With the effect of their LLL model and high numbers of associations and unionization, there is participation in democracy, personal development, increasing life quality, ensuring equality with education, and improving vocational competencies among Denmark's AE goals. Denmark has an educational tradition that is equalitarian and respects the rights of minorities, so this education tradition decreases the affection rate of market conditions on AE. There are providing jobs, teaching read-write, and providing continuous education among the goals of $\mathrm{AE}$ in Turkey.

When the structure of AE in England is examined, it is seen that there are mostly technical and vocational courses in further education colleges which are in the center of AE and organised by local governments. Moreover, Private or Voluntary (Third) Sector Training Organizations see providing job as the main aim, and they provide apprenticeship and work-based learning provisions. Besides these, it is seen that open and distance learning is run. When the structure of AE in Denmark is examined, it is seen that $\mathrm{AE}$ activities are carried out comprehensively by not only public bodies but 
also by different organizations like associations and unions. Another remarkable point in Denmark is that there are general AE services apart from non-formal AE services. This structure is parallel to the formal education system and adults can attend education at any level. In Turkey, AE s a public service that is carried by DGLL under the TMoE. Public education centers that are under the DGLL and common all over the country implements the curriculum prepared by the state. In particular, since the associations are not common and strong, and there is no strong and wide NGO structure in Turkey, associations and NGOs do not have as many AE activities like the ones in Denmark.

When the legal liability in $\mathrm{AE}$ is examined in these countries, it is seen that the legal liability was given to local authorities with the 2009 Act in England which represents the voluntary partnership model. Whereas in Denmark, the legal liability in AE is regulated with the Act on General Adult Education 2008. Moreover, with the Act on Adult Vocational Training Courses and The Act on Non-Formal AE Activity the legal liability was also shared by different organizations. Denmark, representing formalized social partnership model, shares the responsibility of AE with social partners, but it gives the inspection responsibility to the state by laws. In Turkey which represents the state model, the legal liability in AE is regulated with laws, by-laws, and directives by the TMoE. It can be said that the distribution of legal liability in $\mathrm{AE}$ in these countries is parallel with their LLL models.

In the light of this study, lifelong learning and adult education services, which should be seen as a public service, should not be left entirely to the regulation of the market. On the other hand, it is clear that these services cannot be carried out successfully only with the regulation and financing of the state. For this reason, it is important that social partners such as NGOs and employee representatives take responsibility and role in the education and learning of adults, but it is also important that the state also should play an effective role both as a supervisor and financier. Another important issue that emerged in this comparative study is the fact that a centralized management system does not serve an effective and efficient lifelong learning and adult education. In the field of education, as in all public areas, it is seen that a more effective and efficient lifelong learning and adult education service is provided in countries where regional and local governments are given more authority. For this reason, while developing lifelong learning and adult education policies, it is thought that it would be beneficial to adopt a model where the state will assume the role of supervision and financier, cooperation with social partners and where local governments are more active. For future studies, it is recommended to conduct comparative studies that examine lifelong learning and adult education policies and systems in countries where local governments are active and studies that analyse the opinions of social stakeholders.

\section{Ethics Committee Decision}

This study does not include human subjects, thus ethics committee approval decision is not needed. 


\section{References}

Bağcı, Ş. E. (2011). Lifelong Education Policies in Turkey In The Process of European Union Membership [Avrupa Birliğine üyelik sürecinde Türkiye'de yaşam boyu eğitim politikaları]. Ondokuz Mayls University Journal of Education of Faculty [Ondokuz Mayıs Üniversitesi Eğitim Fakültesi Dergisi], 30(2), 139-173. Retrieved from https://www.pegem.net/dosyalar/dokuman/137995-2013101015553-makale7.pdf

Basic Law of National Education [Milli Eğitim Temel Kanunu]. (No. 1739, 06.14.1973). Official Gazette, 14574, 01.24.1973.

Business, Innovation and Skills (BIS). (2010). Skills for sustainable growth. Retrieved from https://www.gov.uk/government/publications/skills-for-sustainablegrowth-strategy-document

Business, Innovation and Skills (BIS). (2013). Rigour and responsiveness in skills. Retrieved from https://www.gov.uk/government/publications/rigour-andresponsiveness-in-skills

Danish Ministry of Education (DMoE) (2007). Denmark's strategy for lifelong learning-Education and lifelong skills upgrading for all. Report to the European Commission. Retrieved from https://planipolis.iiep.unesco.org/en/2007/denmarks-strategy-lifelong-learningeducation-and-lifelong-skills-upgrading-all-report-european

Danish Ministry of Education (DMoE). (2016a). Nonformal adult education. Retrieved from http://eng.uvm.dk/Education/Adult-education-and-continuingtraining/Nonformal-adulteducation

Danish Ministry of Education (DMoE). (2016b). The general adult education programme. Retrieved from http://eng.uvm.dk/Education/Adult-education-andcontinuing-training/The-General-Adult-Education-Programme.

Danish Ministry of Education (DMoE). (2016c). Adult education and continuing training. Retrieved from http://eng.uvm.dk/Education/Adult-education-andcontinuing-training

Decree Law on Organization and Duties of Ministry of National Education [Milli Ĕ̈itim Bakanlı̆̆ının Teşkilat ve Görevleri Hakkında Kanun Hükmünde Kararname]. (No. 6764, 12.02.2016). Official Gazette[Resmi Gazete], 29913, 12.09.2016.

Demirel, M., and Yağcı, E. (2012). Perceptions of Primary School Teacher Candidates About Lifelong Learning [Üniversite öğrencilerinin yaşam boyu öğrenmeye ilişkin algılar1]. Hacettepe University Journal of Educations [Hacettepe Üniversitesi Eğitim Fakültesi Dergisi], 1(Special Issue[Özel Say1]), 100-111. 
EAEAC Eurydice. (2016a). Denmark. adult education and training/main providers. $\quad$ Retrieved from https://webgate.ec.europa.eu/fpfis/mwikis/eurydice/index.php/Denmark:Main_ Providers

EAEAC Eurydice. (2016b). Denmark. Adult Education and Training/Main Types of Provision. Retrieved from https://webgate.ec.europa.eu/fpfis/mwikis/eurydice/index.php/Denmark:Main_ Types_of_Provision

European Commission (EC). (1993). White paper on growth, competitiveness and employment. The challenges and the ways forward forthe 21 st century. Retrieved from file://C:/Users/User/Desktop/gp_eudor_PDFA1B_CM8294529ENC_001.pdf.e n.pdf

European Commission (EC). (2009). Education and Training 2020. Retrieved from http://ec.europa.eu/education/policy/strategic-framework/index_en.htm

EUROSTAT. (2016). Lifelong learning statistics. Retrieved from http://appsso.EUROSTAT.ec.europa.eu/nui/show.do?dataset=trng_lfs_01\&lan $\mathrm{g}=\mathrm{en}$

Field, J. (2010). Lifelong learning. Retrieved from http://booksite.elsevier.com/brochures/educ/PDF/Lifelong_Learning.pdf

Green, A. (2005, September). Models of lifelong learning and the knowledge economy/society in Europe: what regional patterns are emerging? European Conference on Educational Research Conference Preceedings. Retrieved from http://www.leeds.ac.uk/educol/documents/00003902.htm

Kogan, M. (2000). Lifelong learning in the UK. European Journal of Education, 35(3), 343-359.

Larson, A., and Milana, M. (2011). Professionalization of adult educators in Denmark. Denmark International Journal of Continuing Education and Lifelong Learning, 3(2), 75-89.

Milana, M. (2012). Political globalization and the shift from adult education to lifelong learning. European Journal for Research on the Education and Learning of Adults, 3(2), 103-117. doi: 10.3384/rela.2000-7426.rela0070

Nicholls, G. (2000). Professional development, teaching, and lifelong learning: the implications for higher education. International Journal of Lifelong Education, 19(4), 370-377. doi: 10.1080/02601370050110419

Prokou, E. (2004). Globalisation, knowledge society and lifelong learning. Adult Education: A Journal of the Hellenic Adult Education Association, 2, 4-10. 
Regulation on Non-Formal Education Institutions [Milli Eğitim Bakanlı̆̆l Yaygın Eğitim Kurumları Yönetmeliği] (2010). Official Gazette [Resmi Gazete], 27587, 05.21.2010.

Regulation on Vocational and Technical Education [Mesleki ve Teknik Eğitim Yönetmeliği] (2008). Official Gazette [Resmi Gazete], 27003, 09.20.2008.

Rizvi, F., and Lingard, B. (2000). Globalization and education: Complexities and contingencies. Educational Theory, 50(4), 419-426. doi: 10.1111/j.17415446.2000.00419.x

Sayılan, F. (2001). As the paradigm changes: Globalization and lifelong education [Paradigma değişirken: Küreselleşme ve yaşam boyu eğitim]. In A Gift to Cevat Geray [Prof. Dr. Cevat Geray'a armă̆an] (pp. 609-624). Ankara: Union of Political Science Publications [Mülkiyeliler Birliği Yayınları], No: 25.

Smith, A. (2002). The EU Memorandum on Lifelong Learning. C. Medel-Anonuevo (Ed.), In Integrating lifelong learning perspectives (pp. 47-52). UNESCO Institute for Education.

Turkish Ministry of Education (TMoE) [Türkiye Milli Eğitim Bakanlığg] (2009). Turkey Lifelong Learning Strategy Document [Türkiye hayat boyu ögrenme strateji belgesi]. Retrieved from http://mesbil.meb.gov.tr/genel/hayat\%20boyu\%20öğrenme\%20dokuman.pdf

Turkish Ministry of Education (TMoE) [Türkiye Milli Eğitim Bakanlığı] (2014). Turkey lifelong learning strategy document and action plan 2014-2018 [Türkiye hayat boyu ögrenme strateji belgesi ve eylem planı (2014-2018)]. Retrieved from http://hbogm.meb.gov.tr/str/str.html

United Nations Development Programme (UNDP). (2015). Human Development Report. 2015. Retrieved from http://hdr.undp.org/en/data

United Nations Educational, Scientific and Cultural Organization (UNESCO). (1972). Learning to be: The world of education today and tomorrow. Paris: UNESCO.

Vocational Education Law [Mesleki Eğitim Kanunu] (No: 3308, 06.02.1986). Official Gazette [Resmi Gazete], 19139, 06.19.1986.

Vocational Qualifications Institution Law [Mesleki Yeterlilik Kurumu Kanunu] (No: 5544, 21.09.2006). Official Gazette, 26312, 07.10.2006.

Yıldiz, A. (2012). Transformation of adult education in Turkey: Form public education to life-long learning. Kemal İnal, and Güliz Akkaymak (Ed.), In Neoliberal transformation of eductaion in Turkey. (p. 245-257). Palgrave Macmillan. 



\section{Avrupa Birliği’'nin Yaşam Boyu Öğrenme Politikaları Bağlamında İngiltere, Danimarka ve Türkiye'nin Yetişkin Eğitimi Sistemlerinin Karşılaştırmalı Analizi ${ }^{1}$}

\begin{tabular}{|c|c|c|c|}
\hline $\begin{array}{l}\text { MAKALE TÜRÜ } \\
\text { Derleme Makalesi }\end{array}$ & $\begin{array}{c}\text { Başvuru Tarihi } \\
10.02 .2020\end{array}$ & $\begin{array}{c}\text { Kabul Tarihi } \\
01.02 .2021\end{array}$ & $\begin{array}{c}\text { Yayım Tarihi } \\
02.02 .2021\end{array}$ \\
\hline \multicolumn{3}{|c|}{ Rabia Vezne iD 2} & Akdeniz Üniversitesi \\
\hline \multicolumn{4}{|c|}{$\begin{array}{l}\text { Ahmet Yıldız } 3 \\
\text { Ankara Üniversitesi }\end{array}$} \\
\hline \multicolumn{4}{|c|}{ Öz } \\
\hline \multicolumn{4}{|c|}{$\begin{array}{l}\text { Bu araştırmanın amacı AB'ye üye olan, eskiyen üye olan veya aday ülke olan İngiltere, } \\
\text { Danimarka ve Türkiye'de yetişkin eğitiminin hedefleri, yapısı ve yasal sorumluluğunu } \\
\text { karşılaştırarak analiz etmektir. Dolayısıyla bu çalışmanın yöntemi karşılaştırmalı yetişkin } \\
\text { eğitimidir. Bu araştırma insanlar üzerinde yapılmadığ için etik kurul onayı gerekmemektedir. } \\
\text { Araştırmada, söz konusu ülkelerin yetişkin eğitimi sistemlerinin hedefleri, yapısı ve yasal } \\
\text { sorumluluğu karş1laştırılmıştır. Bu araştırmada elde edilen bulgulardan ilki, AB'nin yaşam } \\
\text { boyu öğrenme hedeflerinin her üç ülkenin yetişkin eğitimi hedeflerini etkilemiş olduğudur. Söz } \\
\text { konusu ülkelerdeki yetişkin eğitimi sistemi yapı boyutunda incelendiğinde, yerel yönetimlerin } \\
\text { İngiltere'de etkin olduğu, Danimarka'da üç farklı paydaşın yer aldığı, Türkiye'de ise kamunun } \\
\text { yetişkin eğitiminde ağırlıklı rol aldığ görülmüştür. İngiltere'de yerel yönetimler yasal } \\
\text { sorumluluğu üstlenirken Danimarka'da kamu ve birliklerin bu rolü üstlendiği belirlenmiştir. } \\
\text { Merkeziyetçi bir yapıya sahip Türkiye'de ise yasal sorumluluk merkezdedir. Yetişkin eğitimi } \\
\text { hizmetlerini en başarılı bir şekilde yürüten ülkenin Danimarka olduğu görülmüştür. }\end{array}$} \\
\hline
\end{tabular}

Anahtar sözcükler: Karşıllaştırmalı yetişkin eğitimi, yetişkin eğitimi sistemleri.

\footnotetext{
${ }^{1}$ Bu çalışma Ankara Üniversitesi Eğitim Bilimleri Enstitüsü’nde hazırlanan “Avrupa Birliği'nin Yaşam Boyu Öğrenme Politikaları Bağlamında İngiltere, Danimarka Ve Türkiye’nin Yetişkin Eğitimi Sistemlerinin Karşılaş̧ırmalı Analizi” isimli doktora tezinden üretilmiştir. Tez Danışmanı Doç. Dr. Ahmet Yildız'dir.

${ }^{2}$ Sorumlu Yazar: Dr. Öğr. Üyesi., Eğitim Fakültesi, Eğiitm Bilimleri Bölümü, e-posta: rabiavezne@akdeniz.edu.tr, https://orcid.org/0000-0002-0137-3613

${ }^{3}$ Doç. Dr., Eğitim Fakültesi, Eğiitm Bilimleri Bölümü, e-posta: ahmety72@yahoo.com, https://orcid.org/0000-0002-0158-6168
} 


\begin{abstract}
Amaç ve Önem
Küreselleşme ile birlikte yaşam boyu öğrenmeye yapılan vurgu artmıştır. $A B$ ülkelerinin birçoğunda küresel güçlerce ve bilgi toplumu yaratma gereksinimi nedeniyle yaşam boyu öğrenme desteklenmiştir. Nitekim Avrupa Komisyonu 1996 yılını Yaşam Boyu Öğrenme Avrupa Yılı olarak ilan etmiş ve böylece bu kavram Avrupa'da yaygın biçimde kullanılmıştır. Son dönemlerde, AB'nin yaşam boyu öğrenme politikalarının birliğe üye/aday ülkelerde yetişkin eğitimi sistemlerini şekillendirdiği görülmektedir. Bu araştırmanın amacı AB'ye üye veya aday ülke olan İngiltere, Danimarka ve Türkiye'de yetişkin eğitiminin hedefleri, yapısı ve yasal sorumluluğunu karşılaştırarak çözümlemektir.
\end{abstract}

\title{
Yöntem
}

$\mathrm{Bu}$ araştırmada karşılaştırmalı yetişkin eğitimi yöntemi kullanılmış olup yetişkin eğitimi sistemlerinin ayrı ayrı öğeleri incelenmiş ve farklılıklar saptanmaya çalışılıışıtır. Ülkelerin yetişkin eğitimi sistemlerinin şu öğeleri karşılaştırılmıştır: Hedefler, yapısı ve yasal sorumluluk. Karşılaştırma yapılacak ülkeler, farklılıkların özellikle gönüllü, biçimlendirilmiş ve devlet-güdümlü sosyal ortaklık modelleri arasında olduğunun belirtildiği Green'in (2005) çalışmasındaki sınıflandırma esas alınarak seçilmiştir. Bu nedenle ülkeler bu üç gruptan seçilmiştir. Araştırmada, gönüllü ortaklık modeli için İngiltere, biçimlendirilmiş sosyal ortaklık modeli için Danimarka ve devletçi model için Türkiye seçilmiş ve bu ülkelerin yetişkin eğitimi sistemleri karşılaştırılmıştır. Araştırmada doküman incelemesi ile veriler toplanmıştır. İlk olarak alanyazın taranmış ve karşılaştırma yapabilmek için kategoriler belirlenmiştir. Eurydice Ağı, AB ülkelerinin eğitim sistemleri hakkında güncel bilgiler paylaşan bir oluşumdur. $\mathrm{Bu}$ nedenle Eurydice Ağı'nda belirlenen kategorilerden yetişkin eğitiminin hedefleri, yapısı ve yasal sorumluluk karşılaştırma için seçilmiştir. Karşılaştırmalı araştırmalarda yaşanan sorunlardan biri olan güncel ve ilgili verilere ulaşma sorunu, böyle geniş ve güncel bir alanda verilerin alınmasıyla ortadan kaldırılmıştır. Eurydice A $\breve{g}$ 'ndan özellikle yapı ve yasal sorumluluk boyutları ile ilgili bilgilere ulaşılmıştır. Ayrıca söz konusu ülkelerde bulunan üniversitelerin web sayfaları, bakanlıkların dokümanları ve çeşitli eğitim kurumlarının web sayfalarından da yararlanılmıştır. Söz konusu ülkelerin sosyal, siyasal ve ekonomik yapıları da incelenerek yetişkin eğitimi sistemleri arasındaki benzerlik ve farklılıkların nedenleri araştırılmıştır. Bu sayede karşılaştırmalı eğitimin özüne sadık kalınarak sadece bilgiler sunulmamış aynı zamanda benzerlik ve farklılıkların da altı çizilmiştir. Ayrıca bu araştırma bireyler üzerinde yapılmadığı için etik kurul onayı gerekmemektedir.

\section{Bulgular}

AB'ince yayımlanan belgelerin birçoğunda vurgulanan sözcükler; ekonomik büyüme, rekabet edilebilirlik ve istihdamdır. Hem bireylerin gelişimi hem de toplumun gelişimi doğrudan ekonomik ilerleme ile ilişkilendirilmiş ve rekabet edilebilirliğin göz ardı edilemeyeceği belirtilmiş̧ir. Nihayetinde Avrupa Yeterlilik Çerçevesi gibi uluslarası nitelik çerçeveleri ve uluslararası sınavlarla eğitimde rekabet uluslararası boyutlara taşınmaktadır. Özellikle yetişkinlere yeni yeterliklerin kazandırılmasının önemine vurgu 
yapılmaktadır. Bu amaçların gerçekleştirilebilmesi için de yaşam boyu öğrenmenin altı çizilmektedir. Yetişkin eğitiminin yaşam boyu öğrenme kavramı ile anılmaya başlamasıyla birlikte kamusal niteliğinin de önemli ölçüde aşındığı gözlenmektedir. Kamusal fonların azaltılması sonucunda yetişkin eğitimi ticarileşmiştir. Dönem politikaları ve güncel yaklaşımlarda mesleki eğitime vurgu yapılırken, genel yetişkin eğitimi programlarında bir azalma olmuş, istihdam eksenli düzenlenen eğitim programlarında bir artış olmuştur. Başka bir ifade ile bu yakın dönemde ekonomik pazarın yönlendirmesi doğrultusunda yetişkin mesleki eğitimine vurgu artmış ve mesleki eğitimde uluslararası ölçünler belirlenmiş̧ir. Bu nedenle sivil toplum örgütleri toplumcu bir amaç güden yetişkin eğitimi hizmetlerini üstlenmeye başlamıştır.

Araştrma sonuçları, karşılaştırma yapılan ülkelerin yetişkin eğitimi politikalarının AB'nin politikaları ile koşut olduğunu ortaya çıkarmıştır. Nitekim AB'nin söz konusu politikaları her ülkenin yetişkin eğitimi politikaların benzer şekilde etkilememiştir. $\mathrm{Bu}$ farklılık söz konusu ülkelerin bulunduğu coğrafyadaki eğitim geçmişi ve ülkelerin yönetim biçimlerinden kaynaklanmıştır. İngiltere'de yetişkin eğitimi politikaları ve hedefleri mesleki eğitimi güçlendirmeyi ve işgücüne beceri kazandırmayı amaçlamaktadır. Yeti̧skin eğitiminin bir hak olduğu görüşü halen Danimarka ve Türkiye'nin strateji belgelerinde altı çizilen bir konudur. Danimarka'nın çok uzun bir eğitim geçmişi olmasının ve toplumun örgütlü olmasının yetişkinlerin eğitim hakkının halen ön planda tutulmasında etkili olduğu söylenebilir. Türkiye'nin yetişkin eğitimi amaçları arasında eğitimi sürekli bir hizmet duruma getirmek, bilimsel ve güncel gelişmelere uyum sağlamayı kolaylaştıracak bir eğitim hizmeti sunmak ve piyasaların istemlerine uygun işgücü yetiştirmek yer almaktadır. Türkiye'nin 2014-2018 dönemini kapsayan ikinci Hayat Boyu Öğrenme Strateji Belgesi’nde ise özellikle şu konulara vurgu yapılmaktadır: Ülke genelinde yaşam boyu öğrenme kültürünün geliştirilmesi, firsat eşitliğinin sağlanması, yönlendirme yapılması, önceki öğrenimlerin tanınması ve izleme yapılması.

Söz konusu ülkelerde yetişkin eğitimi yapısına bakıldığında, teknik ve mesleki kursların İngiltere'de yoğunlukta olduğu görülmektedir. Yetişkin eğitimi veren pek çok kurum da meslek edindirmeye odaklanıp işbaşında eğitime önem vermektedir. Yine bu kurumlarda staja ağırlık verilmektedir. Bunlara ek olarak açık ve uzaktan eğitim başarıyla uygulanmaktadır. Bu yapılanma, İngiltere'nin yaşam boyu öğrenme politikalarının AB'nin söz konusu politikaları ile oldukça uyumlu olduğunu göstermektedir. Sosyal ortaklık modelinin uygulandığı Danimarka'da ise bu eğitimlerin hem kamu hem de dernek ve sendikalarca şekillendirildiği göze çarpmaktadır. Örgün ve yaygın yetişkin eğitimi verilmektedir. Ayrıca örgün eğitim sistemine paralel olan genel yetişkin eğitimi hizmeti de bulunmaktadır. Genel yetişkin eğitimi kapsamında yetişkinlere örgün eğitim kapsamında alamadıkları temel dersleri alma firsatı sunulmaktadır. Matematik gibi tek bir temel ders alabildikleri gibi birden fazla ders de alabilmektedirler. Böylece örgün eğitimi tamamlayamayan yetişkin bireyler eğitime herhangi bir aşamada dahil olabilmektedir. $\mathrm{Bu}$ sayede bireylerin yetişkin eğitimine daha fazla katılımları özendirilmektedir. Bu da Danimarka'nın yetişkin eğitimine katılım oranlarını olumlu yönde etkilemektedir. Türkiye'deki durum ise İngiltere ve Danimarka'dan kimi noktalarda farklılaşmaktadır. Yetişkin eğitimi hizmetleri büyük çoğunlukla bir kamu hizmetidir. Milli Eğitim Bakanlığı 
örgüt yapısı altında Hayat Boyu Öğrenme Genel Müdürlüğü bulunmaktadır. Bu genel müdürlüğün altında Halk Eğitimi Merkezleri bulunmaktadır ve bu merkezler ülke genelinde yetişkin eğitimi etkinliklerini ağırlıklı olarak yürütmektedir. Öğretim programları Bakanlık uzmanlarınca hazırlanıp Merkezlerle paylaşılmaktadır. Merkezler bu programları uygulamak zorunda olup merkeziyetçi yapının ağıllığı burada görülmektedir. Türkiye'de dernek sayısı karşılaştırma yapılan diğer ülkelere göre daha az olup yetişkin eğitimi etkinlikleri de bu oranda sınırlıdır. Ayrıca etkin bir sivil toplum kuruluşu (STK) yapısı da bulunmamaktadır. Bu nedenlerden dolayı söz konusu kurumların etkinlikleri daha az kapsamlıdır.

Söz konusu ülkelerde yasal sorumluluğun dağılımına bakıldığında ve karşılaştırma yapıldığında da farklılıklar görülmektedir. Yasal sorumluluk İngiltere'de yerel yönetimlerdedir. Ancak üst kurumların düzenleme yetkisi vardır. Buna ek olarak finansman ve denetim işlerinden de üst kurumlar sorumludur. Kısacası bu ülkede her ne kadar yerel yönetimlere yetki verilse de düzenleme, finansman ve denetim üst kurullarca gerçekleştirilmektedir. Benzer bir uygulama Danimarka'da da görülmektedir. Sosyal ortaklık modelinin uygulandığı Danimarka'da düzenleme yasa ve yönetmeliklerle yapılmaktadır. Dernek ve STK'lar etkin bir şekilde yetişkin eğitimi etkinliklerini sürdürse bile yasal sorumluluk anlamında devlet daha etkin biçimde çalışmakta ve düzenleme yapmaktadır. Devletçi modelin hakim olduğu Türkiye'de yetişkin eğitimi etkinliklerinde yasal sorumluluk tamamen Milli Eğitim Bakanlığına aittir. Söz konusu etkinlikler yasalarla ayrıntılı biçimde belirlenmiştir. Yasalara ek olarak pek çok yönetmelik ve yönerge de yayınlanmaktadır. Green'in (2005) yaptığı sınıflandırma ile söz konusu ülkelerdeki yasal sorumluluğun yapısı benzerlik göstermektedir. Yasal sorumluluğun yerel yönetimlerde bulunduğu İngiltere, Green'in sınıflandırmasında gönüllü ortaklık modelindedir. Danimarka ise sosyal ortaklık modelini benimsemiş̧ir ve bu modele uygun olarak yetişkin eğitiminin sorumluluğu sosyal ortaklarla paylaşılsa bile devlet yasalarla düzenleme ve denetim yapmaktadır. Ayrıca burada farklı bakanlıklar yetkileri paylaşmaktadır. Her ne kadar yerel yönetimler bu eğitimlerin bazılarının sorumluluğunu alsa bile bu eğitimleri yürüten pek çok kurum özerk kamu kurumudur. Türkiye ise tamamen merkeziyetçi bir yapıya sahip olduğu için yetişkin eğitimi etkinliklerinde yasal sorumluluk bütünüyle yasalarla düzenlenmekte ve denetlenmektedir.

\section{Tartışma, Sonuç ve Öneriler}

Avrupa Birliği’'nin 1996 yılını Avrupa Yaşam Boyu Öğrenme Yılı ilan etmesi ile birlikte yaşam boyu öğrenme politikasının küreselleşmeden etkilendiği daha belirgin duruma gelmiştir. Tüm dünyada da insan sermayesi yaklaşımının eğitim politikalarını yönlendirdiği görülmüştür. Bu yaklaşımda bireylerde geliştirilmesi gereken özellikler şu şekilde sıralanmıştır: Öğrenmeyi öğrenmek, kendini sürekli geliştirmek ve rekabete hazır olmak. Küreselleşme ile birlikte bireylerin yaşamları boyunca birden fazla iş değiştirmek zorunda kalacağı belirtilerek öğrenmeyi öğrenmek, kendini sürekli geliştirmek ve rekabete hazır olmak gibi özelliklerin önem kazandığı ve bu nedenle bu özelliklere vurgu yapıldığı belirtilmiştir. Bu nedenle bireylerin sürekli gelişmeye açık olmalarının altı çizilmiştir. Yine bu yaklaşımda işsizliğin sorumluluğu kendini ve becerilerini geliştiremeyen bireye yüklenmiştir. Sonuç olarak esnek bir yaşam boyu öğrenme önerilmiştir. 
Karşılaştırma yapılan üç ülkenin yetişkin eğitimi hedeflerinin AB'nin söz konusu hedefleri ile koşut olduğu görülmektedir. İngiltere'de bu politikalar ve hedefler meslek edindirmeye odaklanırken Danimarka'da yetişkin eğitimine erişimde eşitliğin altı çizilmiştir. Türkiye'nin politikasında ve hedeflerinde ise İngiltere gibi meslek edindirmeye vurgu yapılmakla birlikte okur-yazarlık ile eğitimin sürekliliği de yer almaktadır.

Söz konusu ülkelerdeki sistemlerin yapısı karşılaştırıldığında, farklı yönetim modellerinden kaynaklanan farklı yapılanmalar göze çarpmaktadır. Teknik ve mesleki eğitimler İngiltere'de yoğunlukla görülürken Danimarka'da devletin yanı sıra dernek ve sendikalar gibi farklı sosyal paydaşlarca düzenlenen eğitimler dikkat çekmektedir. Sosyal ortaklık modelinin uygulandığı Danimarka'nın yetişkin eğitiminde örgün, yaygın ve genel yetişkin eğitimi hizmetleri bulunmaktadır. Böylece yetişkin bireyler eğitime herhangi bir aşamada dahil olabilmektedir. Türkiye'deki yapı ise İngiltere ve Danimarka'dan farklı olup yetişkin eğitimi bir kamu hizmetidir. Milli Eğitim Bakanlığı örgüt yapısı altında bulunan Hayat Boyu Öğrenme Genel Müdürlüğüne bağlı Halk Eğitimi Merkezleri ülke genelinde yetişkin eğitimi etkinliklerini yürütmektedir. Danimarka'ya göre Türkiye'de sendikalaşma ve dernekleşme daha az yaygın olduğu için kamu ağırlıklı bir yetişkin eğitimi yapısı bulunmaktadır.

Yasal sorumluluk açısından ülkeler karşılaştırıldığında yönetim modellerine uygun bir yap1 görülmektedir. İngiltere'de yasal sorumluluk yerel yönetimlerde iken Danimarka'da düzenleme yasalarla yapılmaktadır. Devletçi modelin hakim olduğu Türkiye'de ise sorumluluk Milli Eğitim Bakanlığı'ndadır. Devletçe yürürlüğe konulan yasa, yönetmelik ve yönergelerle yetişkin eğitimi hizmetleri düzenlenmektedir.

Bir kamu hizmeti olarak görülmesi gereken yaşam boyu öğrenme ve yetişkin eğitimi hizmetlerinin tamamen piyasanın düzenlemesine bırakılmaması gerektiği, sadece devletin düzenlemesi ve finansmanı ile de bu hizmetlerin başarılı biçimde yürütülemediği açıktır. $\mathrm{Bu}$ nedenle yetişkinlerin eğitiminde STK ve işçi temsilcileri gibi sosyal ortakların da sorumluluk ve görev alması ancak devletin de hem denetleyici hem de finansör olarak etkili bir rol oynaması önemlidir. Yapılan bu karşılaştırmalı çalışmada ortaya çıkan diğer önemli bir konu da merkeziyetçi bir yönetim sisteminin etkili ve verimli bir yaşam boyu öğrenme ve yetişkin eğitimine hizmet etmediği gerçeğidir. Tüm kamu alanlarında olduğu gibi eğitim alanında da bölgesel ve yerel yönetimlere daha fazla yetkinin verildiği ülkelerde daha etkili ve verimli bir yaşam boyu öğrenme ve yetişkin eğitimi hizmeti sunulduğu görülmektedir. Bu nedenle yaşam boyu öğrenme ve yetişkin eğitimi politikaları geliştirilirken devletin denetim ve finansör rolünü üstleneceği, sosyal ortaklarla işbirliğinin yapıldığı ve yerel yönetimlerin daha etkin olduğu bir modelin benimsenmesinin yararlı olacağ 1 düşünülmektedir. Gelecek çalışmalar için özellikle, yerel yönetimlerin etkin olduğu ülkelerdeki yaşam boyu öğrenme ve yetişkin eğitmi politika ve sistemlerinin incelendiği ve sosyal paydaşların görüşlerinin alındığı karşılaştırmalı çalışmaların yapılması önerilmektedir.

\section{Etik Kurul Kararı}

$\mathrm{Bu}$ araştırma bireyler üzerinde yapılmadığı için etik kurul onayı gerekmemektedir. 